\title{
The influence of principal managerial ability and teacher performance toward senior
}

\section{high school quality}

\author{
Sowiyah ${ }^{1^{*}}$ \\ Zulaikha Fitriyanti \\ Veronica Eka Desi Natalia ${ }^{3}$ \\ 1,2,3 Faculty of Teacher Training and Education, Universitas Lampung, Bandar Lampung, Indonesia
}

\begin{abstract}
The current research aimed to analyze and determine the effect of principal managerial ability and teacher performance on the quality of senior high school in Way Kanan regency. This research is quantitative using a descriptive verification method with a cluster random sampling technique with a sample of 235 teachers of Way Kanan regency. Data were collected using a questionnaire. The collected data were analyzed through multiple equation regression with the help of SPSS Statistics 17 software and then interpreted. The results of this study indicate that there was an influence of principal managerial ability on school quality by $63.7 \%$. In addition, there was an influence of teacher performance on school quality by $58.6 \%$, and finally there was an effect of principal managerial ability and teacher performance on school quality by $68.2 \%$. The implications of the current findings are also discussed.
\end{abstract}

\section{KEYWORDS}

Principal managerial ability; teacher performance; senior high school quality

Received: 13 October 2021

Accepted: 27 October 2021 Published: 15 November 2021

\section{Introduction}

Education is critical to a nation's progress. Education is beneficial because it serves as the foundation for expertise, excellence, and knowledge across all disciplines and social and economic contexts. To maximise these potentials, it is necessary to establish a high-quality education system for a new generation of secondary school students. According to Qiang Tang, Assistant Director General of Education at UNESCO (the United Nations Educational, Scientific and Cultural Organization), the issue of education quality is not unique to Indonesia (GEM). According to a 2016 report in Jakarta, Indonesia is ranked $5^{\text {th }}$ in the world out of 108 countries, behind Thailand, with a 0.603 index. Numerous factors contribute to the low quality of education in Indonesia, including limited access to education, low teacher quality, insufficient educational facilities and infrastructure, and school principals' managerial ability is still considered lacking. According to (Haningsih, 2014) there are numerous quality issues in education, ranging from graduate quality, teaching, teacher guidance and training, to teacher professionalism and performance.

School is an institution that is prepared to provide the needs of quality human resources. The quality of a country also will increase if the existing human resources have good quality. Therefore, efforts to improve the quality of human resources cannot be separated from education. Based on (Law No 20 of 2003 Concerning The National Education System, n.d.) concerning the National Education System Chapter IV, Article 5 Paragraph 1 states that every citizen has the same rights in obtaining quality education. Quality education has become a demand at this time.

According (Engkoswara \& Komariah, 2010) there are "seven indicators for improving school quality, namely: (1) the school environment is safe and orderly; (2) schools that have a vision and quality of targets to be achieved; (3) the school has strong leadership; (4) the existence of high expectations from school personnel to excel; (5) there is self-skill development for school staff according to the demands of science and technology on an ongoing basis; (6) there is a continuous evaluation of various academic and administrative aspects; (7) intensive communication and support from parents/ community". Education quality is often defined as the characteristics of educational services in accordance with certain criteria to meet the satisfaction of education customers, namely students, parents and other interested parties (stakeholders). Quality of education is the level of achievement of the benefits 
of input, process, output and outcome that are adjusted to national education standards that are felt by users of educational services.

Regarding the current important issue, namely the quality of education in schools, there are still many schools that are not of good quality in Indonesia, especially in the suburbs or better known as deepest, remote and disadvantaged areas, so there are still many schools that are still struggling to improve infrastructure physical school and has not reached the overall quality. School quality is an important point for the continuous improvement of the quality of Indonesian human resources.

Way Kanan Regency is one part of the territory of Indonesia which is located in the province of Lampung. Human resource development in Way Kanan Regency is still in the lower middle category, this situation is positively correlated with the low level of education of the population, this situation greatly affects the socio-economic conditions that are vulnerable to the condition of the poor (Vicious Cycle). The low level of education in Way Kanan district is influenced by several factors such as the lack of school facilities, inadequate school buildings, and the low teaching ability of teachers.

Based on the results of the initial observations that the researcher made on the condition of high schools in Way Kanan regency, the found several facts that showed that the quality of high schools was not optimal. The data showing the quality of schools in Way Kanan regency is by looking at the acquisition of school accreditation. The accreditation assessment process is carried out by an institution that is competent in quality assurance which in this case is carried out by the National Accreditation Board. The following is high school accreditation data in Way Kanan regency presented in table below.

Table 1. High School Accreditation Score in Way Kanan Regency

\begin{tabular}{ccc}
\hline Accreditation & Total & Precentage \\
\hline A & 1 & $2,5 \%$ \\
B & 20 & $50 \%$ \\
C & 19 & $47,5 \%$ \\
\hline Source: reference data from the Ministry of Education and Culture, Way Kanan Regency
\end{tabular}

The data above shows that how far the achievement of the quality of education high schools in Way Kanan regency. It can be seen that the quality of senior high schools in Way Kanan regency is still far from expectations. Accreditation of schools still tends to be at a "Good" or B accreditation score of 50\%, and a "Good enough" or C accreditation score of 47.5\%. Meanwhile, for schools with "Excellent" or A accreditation, only 2.5\%, whereas in order to become a quality school, the achievement of the accreditation score must achieve an "Excellent" or A grade. This is not in accordance with the vision set by the Department of Education, Youth and Sports of Way Kanan regency, namely "improving the quality of community life and the competence of regional human resources by improving the education quality of services". Therefore, improving the quality of senior high schools in Way Kanan Regency requires acceleration and proper management in order to achieve the expected vision.

In addition, the results of observations made by researchers regarding the quality of high schools in Way Kanan Regency show facts about limited school facilities and infrastructure so that it has an impact on the acquisition of school accreditation scores which tend to obtain B and C grades, due to the lack of such facilities and infrastructure. One of the indicators that can show that the quality of senior high schools in Way Kanan regency is not optimal is by looking at the output aspect, namely the achievement Graduate Competency Standards by students. Based on the data obtained by the author from several schools in Way Kanan Regency, the achievement of graduate competence standard ranges from $60-80 \%$.

Meanwhile, to improve the quality of schools, the principal role is held by the school principal. The ability of a principal in managing all school activities will have an impact on the quality of the school. One of the principal abilities that is crucial to improving the quality of education is managerial ability. A principal as a manager is required to be able to have readiness in managing the school. Readiness in question is related to the managerial ability of the principal as a leader. (Terry, 1972) explain that "the intended managerial ability is related to its ability to make planning, organizing, implementing, and controlling. It is hoped that every leader with such abilities will be able to become a driver and enforcer of discipline for his employees so that they are able to show their work productivity well".

This is in accordance with (Damayanti, 2017) research results, in his research the managerial ability of school principal has a positive and significant effect on school quality. This is indicated by the average number on the principal managerial ability instrument has a strong effect on school quality. Therefore, the high and low quality of the school is influenced by the managerial ability of the principal.

In another study conducted by (Salim, 2017) it was also found that there was a significant and positive influence between managerial ability on the effectiveness of school management. The contribution of managerial ability to the school management effectiveness variable is $60.6 \%$. The variance of school management effectiveness can be influenced by the managerial ability variable.

Managerial ability is an ability that must be possessed by the principal. According to (Barkah, 2017) "Managerial ability is the ability to utilize existing resources in an effort to move others to achieve organizational goals efficiently and effectively". Another opinion was put forward by (Lunenburg \& Irby, 2006) "manajerial skill 
based on the type of skills needed to do the job. The planning, organizing, leadership, and monitoring skills required for principals are to perform their functions and roles have been placed in three categories, namely conceptual, human, and technical".

Meanwhile, according to (Hersey, 2012) "in order to carry out managerial tasks, three types of skills are needed, namely: technical, human and conceptual. If the principal has the three basic skills mentioned above, the principal can carry out his main duties and functions in accordance with the provisions, so as to achieve the goals of quality education". Therefore, the managerial ability of the principal is characterized by the ability to make decisions and take appropriate, accurate and relevant actions. The three managerial abilities of the principal are characterized by the ability to formulate work programs, to coordinate the implementation of work programs, both with teachers and other parties related to education, and the implementation of evaluation of school work programs.

The managerial ability of the principal is the capacity possessed by a principal in managing the organization and existing resources, in order to achieve organizational goals which include: (1) the ability to plan with indicators, namely being able to formulate and implement strategies, and be able to make planning effective; (2) the ability to organize with indicators capable of departmentalizing, dividing responsibilities and being able to manage personnel; (3) the ability to implement with indicators, namely being able to make decisions, and be able to establish communication; (4) Ability to carry out monitoring of indicators capable of managing, and able to control operations.

School quality is not only influenced by the managerial ability of the principal, but also the performance of teachers. High teacher performance is considered to have implications for the quality of learning which ultimately leads to an increase in student learning achievement (Mulyani, 2012). In line with this, research conducted by (Azhari \& Kurniadi, 2016) "concluded that the management of education financing and learning facilities has an influence on the quality of education".

Teachers as educators are educational leaders, teachers play an important role in the learning process in the classroom, and this role will be reflected in how teachers carry out their roles and duties, this means that performance of teacher is a factor that greatly determines the quality of learning/education which will have implications for quality educational output after finishing school. According to Armstrong and Baron in (Wibowo, 2007) "performance is the result of work related to customer satisfaction and contributes to the economy in the strategic goals of an organization". Meanwhile, according to (Suharsaputra, 2010) "teacher performance is basically a performance carried out by teachers in carrying out their duties as educators".

In addition, according to (Kosim, 2007) what is meant by "in the teaching and learning process, teacher performance is the ability or skill of the teacher to create an educative atmosphere in communication between teachers and students which includes a cognitive, affective, and psychomotor atmosphere as an effort to achieve teaching goals based on planning to evaluation and follow-up". With regard to the competencies that professional teachers need to possess, (Teacher and Lecturer Law No. 14 of 2005 Article 8 and Permendiknas No. 13 of 2007 Concerning School Principal Performance Standards, n.d.), it is stated that there are four competencies that must be possessed by teachers, namely: pedagogic competence, professional, personal, and social competence.

According to (Mulyani, 2012) teacher performance indicators include: 1) the ability to plan and prepare for teaching; 2) mastery of the material to be taught to students; 3) mastery of teaching methods and strategies; 4) provide structured assignments; 5) ability to manage class; 6) the ability to conduct assessments and evaluations.

The low performance of teachers in carrying out a task will affect the achievement of educational goals. Thus, in these conditions the role of the principal is very important to provide a climate that allows teachers to work with enthusiasm. Principals with good managerial skills can build and maintain positive teacher performance.

As a result of the explanation above, it is clear that the quality of schools is influenced by a variety of factors, including the principal's leadership, his or her ability, the school's facilities and infrastructure, financial management, and teacher performance. All of these components muct be examined in order to determine the factors that affect the quality of senior high schools in the Way Kanan regency. In the light of these circumstances, researchers are interested in conducting a more in-depth examination of the Way Kanan regency.

\section{Literature review}

\section{Principal managerial ability}

Ability is knowledge, skills, and basic values that are reflected in the habits of thinking and acting consistently that enable it to be competent in carrying out its authority, duties, and responsibilities (Wahyudi, 2009). Basically, principals in carrying out their duties as administrators cannot be separated from managerial competencies, namely conceptual skills, human skills, and technical skills. (Siswanto, 2011) explains that managerial skills are divided into three types of managerial skills that need to be mastered by educational leaders especially principals consisting of: (1) conceptual skills is the ability of principals to understand and operate the organization of school; (2) human relations skills is skills to work together, motivate, and lead the organization and; (3) technical skills mean skills in using certain knowledge, methods, strategies, techniques in an organization. 
A school principal is required to be able to bring the school he leads into a quality school by having good managerial skills so that he can become a role model for school residents. The principals abilities include personality competencies, managerial abilities, entrepreneurial competencies, supervisory competencies, and social competencies (Putrayana et al., 2018; Sugihartini et al., 2018). The principal is the main factor in a quality school by realizing the vision, mission, achievements, and goals of the school he leads (Kuswana, 2019). Skilled leaders can reflect on future needs and empower other resources to share and implement the vision properly (Laksmi et al., 2019; Yayuk \& Sugiyono, 2019). Based on these, it can be concluded that the principal's managerial ability is able to operate a management process that refers to the management function, besides that the principal is also requir ed to understand and apply all the substance organization of educational activities.

\section{Teacher performance}

Performance is the result of work achieved by a person in carrying out the tasks assigned to him based on ability, experience and seriousness as well. Performance refers to the level of achievement of tasks that make a person meet the requirements of the job. This reflects that a person can carry out the demands of his job well (Junianto \& Wagiran, 2013; Sulaefi, 2017). The professional task of the teacher is to educate, teach, and train students to achieve satisfactory learning achievements. The function and role of the teacher in teaching and learning activities have a strategic meaning in achieving educational goals. Therefore, a teachers must be able to show work achievements and be able to carry out the tasks given by the manager (principal). Meanwhile, according to (Sedarmayanti, 2010) "performance is the result of the function of a particular job or activity during that period. According to this understanding, there are three aspects that need to be understood, namely: clarity of tasks or work that is their responsibility, clarity of expected results from work or functions and time to complete work so that results can be realized".

Teacher performance is the most important part in improving the quality of education. Therefore, peer assessment is something that needs to be taken seriously, especially by school principals and supervisors (Mudiyantun, 2019; Mustikeni, 2019). Teacher performance requires a system to link the goals of the institution with the goals in the learning process, so that there is a common understanding of what must be achieved and how to manage people in the right way to achieve a goal (Arcaro et al., 2018). So it can be concluded that, teacher performance is a condition that shows the ability of teachers to carry out their duties at school and illustrates the existence of an action shown by the teacher in carrying out learning activities.

In other opinion, (Soedijarto, 2011) states that "there are four tasks of a group of abilities that must be mastered by a teacher. The abilities that must be mastered by a teacher are (1) planning teaching and learning programs; (2) implement and lead the teaching and learning process; (3) assessing the progress of the teaching and learning process; (4) build relationships with students". Based on this understanding, it can be seen that what is meant by the concept of teacher performance is the result of work or work performance carried out by a teacher based on the ability to manage teaching and learning activities, which include planning, implementing, evaluating and fostering interpersonal relationships with students.

\section{School quality}

In general, quality is the overall description and characteristics of the field or service that indicate the ability to satisfy the expected or implied needs. The definition of quality in the context of education includes input, process, and output of education. Quality education is not something that happens by itself, but is the result of an educational process that runs well, effectively and efficiently. According to (Arcaro, 2005) "quality is a comprehensive description and characteristics of a product or service that indicate its ability to meet expected needs". According to (Nasution, 2001), "the quality of a product is the suitability of the use of the products to meet the needs and customer satisfaction. The quality is conformance to requirement, which is in accordance with the required quality standard or the standardized quality". A product has quality when it is in accordance with the quality standards that have been determined.

The (National Education, 2002) stated that the school quality inclusively contains elements of an effective school which is based on the process input and output. This means that the indicators of the quality of schools are a reference to develop the details of the quality assessment. These indicators are elaborated from many aspects that become the focus of the assessment and they are developed from the dimensions of the quality based on the construct of the school quality. The quality of school graduates the one most telling indicators for a country educational status. Quality schools are schools that have the ability to develop the basic potential of students and educators to the fullest, which is measured by the value of developing knowledge and things that are more personal (Aspin et al., 1994). According to (Zeithaml \& Bitner, 2002) "there are ten determining factors in achieving the quality of education services, namely: (1) reliability; (2) interdependency; (3) competencies; (4) access; (5) ethics and politeness); (6) communications; (7) credibility; (8) security; (9) understand the needs of customers; and (10) tangibles". From this explanation, it can be understood that the concept of the quality requires education providers to understand and realize that the product is not school but goods or services education services.

The quality indicator as developed by (Sallis, 2002) provides data about "the contribution of each indicator to the improvement of the quality of such as: (1) effective learning and teaching; (2) leadership; (3) employees; (4) 
students; (5) standards; (6) organization; (7) physical environment and resources; (8) external relations; (9) access and; (10) service to special event. The concept of the indicators of School Quality that developed by Taylor, West, \& Smith from Utah State University in 2006 has seven indicators to assess the quality. The seven quality indicators are: (1) support of parents; (2) teacher quality; (3) student commitment; (4) school leadership; (5) quality of learning; (6) resource management, and (7) school safety".

\section{Methods}

This study uses a quantitative approach to determine the effect of principal managerial ability and teacher performance on school quality in Way Kanan district. The uses descriptive verification method which aims to describe whether the facts are true or not, and explain the relationship between the variables studied by collecting data, processing, analyzing and interpreting the data in statistical hypothesis testing.

The data collection technique in this study was through questionnaires, using a closed type of questionnaire, namely a research questionnaire with a list of questions or statements that have been completed with answer choices at once (Sugiyono, 2017). The population in this study were 40 high schools with 571 teachers in Way Kanan Regency. This study uses a cluster random sampling area technique. In this study, a sample of 235 respondents was selected. The research analysis used multiple equation regression with the help of SPSS Statistics 17 software and then estimated.

\section{Results}

Hypothesis testing was carried out using the SPSS Statistics 17 program. The data revealed in this study were school quality $(\mathrm{Y})$, principal managerial leadership $\left(\mathrm{X}_{1}\right)$ and teacher performance $\left(\mathrm{X}_{2}\right)$. The overall data obtained are each sought for the highest value, lowest value and average. The findings and discussion are presented descriptively for each variable and each relationship between variables are discussed as follows.

Table 2. Regression of principal managerial ability on school quality

\begin{tabular}{|c|c|c|c|c|c|c|}
\hline \multicolumn{7}{|c|}{ Coefficients $^{\mathrm{a}}$} \\
\hline & \multirow{2}{*}{ Model } & Unstar & Coefficients & $\begin{array}{l}\text { Standardized } \\
\text { Coefficients }\end{array}$ & $\mathrm{t}$ & Sig. \\
\hline & & $\mathrm{B}$ & Std. Error & Beta & & \\
\hline \multirow[t]{2}{*}{1} & (Constant) & 4.858 & 1.439 & & 3.376 & .001 \\
\hline & $\begin{array}{l}\text { Principal } \\
\text { Managerial Ability }\end{array}$ & .867 & .043 & .798 & 20.202 & .000 \\
\hline
\end{tabular}

\begin{tabular}{|c|c|c|c|c|c|c|}
\hline \multicolumn{7}{|c|}{ a. Dependent Variable: School Quality } \\
\hline \multicolumn{7}{|c|}{ ANOVA $^{\mathrm{b}}$} \\
\hline & Model & Sum of Squares & Df & Mean Square & $\mathrm{F}$ & Sig. \\
\hline \multirow[t]{3}{*}{1} & Regression & 1734.690 & 1 & 1734.690 & 408.140 & $.000^{\mathrm{a}}$ \\
\hline & Residual & 990.305 & 233 & 4.250 & & \\
\hline & Total & 2724.996 & 234 & & & \\
\hline
\end{tabular}

a. Predictors: (Constant), Principal Managerial Ability

b. Dependent Variable: School Quality

Based on the results of the analysis in table 2 obtained as follows.

1. Constant $\mathrm{a}=4.858$ and coefficient $\mathrm{b}_{1}=0.867$ so that the regression equation becomes $\hat{Y}=4.858+0.837 \mathrm{X}_{1}$.

2. The constant a of 4.858 states that if there is no value of the principal's managerial ability variable $(\mathrm{X}=0)$ then the average school quality score is 4.858 .

3. The regression coefficient for $\mathrm{X}_{1}$ is 0,867 which states that each addition of one variable $\mathrm{X}$ will increase the $\mathrm{Y}$ variable or if the managerial ability of the principal is good, it will increase the quality of the school by 0.867 . When viewed from the probability (sig.) it turns out to be $0.0001<0.05$, thus $\mathrm{H}_{0}$ is rejected and $\mathrm{H}_{\mathrm{i}}$ is accepted, meaning that the influence of the principal's managerial ability on school quality is very significant. 
Table 3. Coefficient of determination of principal managerial ability on school quality

\begin{tabular}{lcccc}
\hline \multicolumn{5}{c}{ Model Summary } \\
\hline Model & $\mathrm{R}$ & R Square & Adjusted R Square & $\begin{array}{c}\text { Std. Error of the } \\
\text { Estimate }\end{array}$ \\
\hline $\mathbf{1}$ & $.798^{\mathrm{a}}$ & .637 & .635 & 2.062 \\
\hline
\end{tabular}

a. Predictors: (Constant), Principal Managerial Ability

Furthermore, in table 2 it can be seen that the magnitude of the coefficient of determination (R Square) is 0.637. The value of the coefficient of determination shows the contribution of the influence of the principal managerial ability to the quality of the school by $63.7 \%$, while the remaining $36.33 \%$ is influenced by other factors.

Table 4. Teacher performance regression on school quality

\begin{tabular}{|c|c|c|c|c|c|c|}
\hline \multicolumn{7}{|c|}{ Coefficients $^{\mathrm{a}}$} \\
\hline \multicolumn{2}{|l|}{ Model } & \multicolumn{2}{|c|}{ Unstandardized Coefficients } & $\begin{array}{l}\text { Standardized } \\
\text { Coefficients }\end{array}$ & $\mathrm{t}$ & Sig. \\
\hline & & $\mathrm{B}$ & Std. Error & Beta & & \\
\hline \multirow[t]{2}{*}{1} & (Constant) & 7.576 & 1.451 & & 5.222 & .000 \\
\hline & Kinerja Guru & .780 & .043 & .766 & 18.165 & .000 \\
\hline \multicolumn{7}{|c|}{ a. Dependent Variable: School Quality } \\
\hline \multicolumn{7}{|c|}{ ANOVA $^{b}$} \\
\hline \multicolumn{2}{|l|}{ Model } & Sum of Squares & Df & Mean Square & $\mathrm{F}$ & Sig. \\
\hline \multirow[t]{3}{*}{1} & Regression & 1597.160 & 1 & 1597.160 & 329.958 & $.000^{\mathrm{a}}$ \\
\hline & Residual & 1127.836 & 233 & 4.840 & & \\
\hline & Total & 2724.996 & 234 & & & \\
\hline \multicolumn{7}{|c|}{ a. Predictors: (Constant), Teacher Performance } \\
\hline b. Depe & endent Variable & ool Quality & & & & \\
\hline
\end{tabular}

Based on the results of the analysis in table 4 obtained as follows.

1. Constant $\mathrm{a}=7.576$ and coefficient $\mathrm{b}_{2}=0,780$ so that the regression equation becomes $\hat{Y}=7.576+0.780 \mathrm{X}_{1}$.

2. The constant a of 7.576 states that if there is no teacher performance variable value $(X=0)$ then the average school quality score is 7.576 .

3. The regression coefficient for $\mathrm{X}_{2}$ is 0.780 which states that each addition of one variable $\mathrm{X}$ will increase the $\mathrm{Y}$ variable or if the teacher's performance is good it will increase the quality of the school by 0.780 .

When viewed from the probability (sig.) it turns out to be $0.0001<0.05$, thus $\mathrm{H}_{0}$ is rejected and $\mathrm{H}_{\mathrm{i}}$ is accepted, meaning that the effect of teacher performance on school quality is very significant.

Table 5. Coefficient of determination of teacher performance on school quality

\begin{tabular}{lcccc}
\hline \multicolumn{4}{c}{ Model Summary } \\
\hline Model & $\mathrm{R}$ & R Square & Adjusted R Square & Std. Error of the Estimate \\
& & & \\
\hline $\mathbf{1}$ & $.766^{\mathrm{a}}$ & .586 & .584 & 2.200 \\
\hline a. Predictors: (Constant), Teacher Performance & & \\
\hline
\end{tabular}

Furthermore, in table 5 it can be seen that the magnitude of the coefficient of determination (R Square) is 0.586. The value of the coefficient of determination shows the contribution of the influence of teacher performance on the quality of schools by $58.6 \%$, while the remaining $41.4 \%$ is influenced by other factors. 
Table 6. Principal managerial ability regression and teacher performance on school quality

\begin{tabular}{|c|c|c|c|c|c|c|}
\hline \multicolumn{7}{|c|}{ Coefficients $^{\mathrm{a}}$} \\
\hline \multirow{2}{*}{\multicolumn{2}{|c|}{ Model }} & \multicolumn{2}{|c|}{ Unstandardized Coefficients } & \multirow{2}{*}{$\begin{array}{c}\text { Standardized } \\
\text { Coefficients } \\
\text { Beta }\end{array}$} & \multirow[t]{2}{*}{$\mathrm{t}$} & \multirow[t]{2}{*}{ Sig. } \\
\hline & & B & Std. Error & & & \\
\hline \multirow[t]{3}{*}{1} & (Constant) & 2.972 & 1.387 & & 2.142 & .033 \\
\hline & Principal Managerial Ability & .559 & .067 & .515 & 8.385 & .000 \\
\hline & Teacher Performance & .362 & .063 & .355 & 5.783 & .000 \\
\hline
\end{tabular}

a. Dependent Variable: School Quality

\begin{tabular}{|c|c|c|c|c|c|c|}
\hline \multicolumn{7}{|c|}{ ANOVA $^{\mathrm{b}}$} \\
\hline Model & & Sum of Squares & $\mathrm{df}$ & Mean Square & $\mathrm{F}$ & Sig. \\
\hline \multirow[t]{3}{*}{1} & Regression & 1859.474 & 2 & 929.737 & 249.213 & $.000^{\mathrm{a}}$ \\
\hline & Residual & 865.522 & 232 & 3.731 & & \\
\hline & Total & 2724.996 & 234 & & & \\
\hline
\end{tabular}

a. Predictors: (Constant), Teacher Performance, Principal Managerial Ability

b. Dependent Variable: School Quality

Based on the results of the analysis in table 6 obtained as follows.

1. Constant $\mathrm{a}=2.972$ and coefficient $\mathrm{b}_{1}=0.559 \mathrm{~b}_{2}=0.362$ so that the regression equation becomes $\hat{Y}=2.972$ $+0.559 \mathrm{X}_{1}+0.362 \mathrm{X}_{2}$.

2. The constant a of 2.972 states that if there is no value for the managerial ability of the principal and teacher performance $(X=0)$ then the average school quality score is 2.972 .

3. The regression coefficient for $\mathrm{X}_{1}$ of 0.559 states that each addition of one variable $\mathrm{X}$ will increase the $\mathrm{Y}$ variable or if the managerial ability of the principal is good it will increase the quality of the school by 0.559 .

4. The regression coefficient for $\mathrm{X}_{2}$ is 0.362 which states that each addition of one variable $\mathrm{X}$ will increase the $\mathrm{Y}$ variable or if the teacher's performance is good it will increase the quality of the school by 0.362 .

When viewed from the probability (sig.) it turns out to be $0.0001<0.05$, thus $H_{0}$ is rejected and $H_{i}$ is accepted, meaning that the effect of principal managerial ability and teacher performance on school quality is very significant.

Table 7. Coefficient of determination of principal managerial ability and teacher performance on school quality

\begin{tabular}{lcccc}
\hline \multicolumn{4}{c}{ Model Summary } \\
\hline Model & $\mathrm{R}$ & $\mathrm{R}$ Square & Adjusted R Square & $\begin{array}{c}\text { Std. Error of the } \\
\text { Estimate }\end{array}$ \\
\hline $\mathbf{1}$ & $.826^{\mathrm{a}}$ & .682 & .680 & 1.932
\end{tabular}

a. Predictors: (Constant), Teacher Performance, Principal Managerial Ability

Furthermore, in table 7 it can be seen that the magnitude of the coefficient of determination (R Square) is 0.682. The value of the coefficient of determination shows the contribution of the influence of the principal managerial ability and teacher performance on the quality of the school by $68.2 \%$, while the remaining $31.8 \%$ is influenced by other factors.

\section{Discussion}

\section{The influence of principal managerial ability on school quality}

Based on this analysis, it is explained that the results of the statistical analysis between the managerial ability of the principal on the quality of the school in table 3 obtained a correlation coefficient $(r)=0.798$ and a coefficient of determination $\left(r^{2}\right)=0.637$. The analysis explains that the principal managerial ability contributes to 
school quality by $63.7 \%$. This shows that, there is a considerable influence between the managerial ability of the principal on the quality of the school.

The principal as a manager is a determinant of success in achieving school quality. The results of research (Suyatno, 2010) show that there is a positive relationship between the quality of the principal (integrity) and the quality of the school. The quality of the principal includes the quality in managerial leadership. With regard to the principal duties as a manager, it is absolutely necessary for the principal to have managerial abilities in order to run the school effectively and efficiently. School progress cannot be separated from the managerial abilities possessed by the principal, because in essence management is a managerial process or the implementation of management functions in schools carried out by the principal. This is supported by the results of research (Salim, 2017) that increasing the effectiveness of management can be done by strengthening the managerial abilities of school principals.

Based on the exposure and research result above, it is concluded that there is an influence of the managerial ability of the principal on the quality of the school. Whatever the size of the contribution given by the managerial ability of the principal will always affect the quality of the school. Therefore, a positive increase that occurs in the principal managerial ability will improve the quality of the school.

\section{The influence of teacher performance on school quality}

Based on this analysis, it is explained that the results of statistical analysis between teacher performance and school quality in table 5 obtained a correlation coefficient $(r)=0,766$ and a coefficient of determination $\left(r^{2}\right)=$ 0,586 . The analysis explains that teacher performance contributes to school quality by $58,6 \%$. This shows that there is an influence between teacher performance on school quality.

Teacher performance is a form of work performance shown by teachers to schools/organizations. Performance can be used as a measure of the extent to which the success of the school/organization in achieving the goals that have been set, performance is often used as a term to refer to the achievement or level of success of individuals and groups. Work success will be demonstrated through the success of the organization in achieving its goals or targets. Teachers are said to have good performance if they are able to produce good work performance, the work performance in question is none other than quality, quantity and completion time in accordance with the work standards set (Ghazzawi et al., 2017).

Based on the results of research by (Timur et al., 2009), it is known that "teacher performance has a relationship with school quality and has an influence. This can be interpreted that variations that occur in the school quality variable regarding teacher performance are predicted to have an effect on improving school quality". From the results of the study, it can be concluded that the teacher performance in education is very important in achieving the goals for the learning process to be achieved.

Based on the opinions and research results above, that there is an influence and linear regression as well as a positive correlation between teacher performance and school quality proves the theory which states that teacher performance can improve school quality in the literature in line with the proposed framework.

\section{The influence of principal managerial ability and teacher performance on school quality}

The results of data processing based on hypothesis testing that have been carried out between the influence of the principal managerial ability $\left(\mathrm{X}_{1}\right)$, teacher performance $\left(\mathrm{X}_{2}\right)$ on school quality $(\mathrm{Y})$ in table 7 obtained the correlation coefficient $(r)=0.826$ and the coefficient of determination $\left(r^{2}\right)=0.682$. The analysis explains that the principal managerial ability and teacher performance contribute to school quality by $68.2 \%$, while $31.8 \%$ is influenced by other factors. This shows that there is a significant influence between the variables of principal managerial ability $\left(\mathrm{X}_{1}\right)$ and teacher performance $\left(\mathrm{X}_{2}\right)$ on school quality $(\mathrm{Y})$.

Researchers analyzed the factors that can support the achievement of school quality from the managerial ability of the principal and teacher performance. In this study, the principal managerial ability is seen from the dimensions of planning, organizing, actuating and controlling. Meanwhile, teacher performance that supports school quality is seen from the aspects of the ability to plan for learning, mastery of the material to be teaching to students, prepare of teaching methods and strategies, providing structured assignments, ability to manage classes and ability to conduct assessments and evaluations. These results are supported by the results of research by (Mulyani, 2012) that simultaneously the performance of the principal and the teacher performance has a significant effect on the quality of learning. The rest is the influence that comes from other factors. Thus, it is clear that the principal performance and the teacher performance have a significant influence on the quality of learning.

The quality of the schools studied in this study is seen from four dimensions, namely input and content, process, output, and accountability. The achievement of school quality, which is supported by the principal managerial ability and teacher performance, is an option to achieve good school quality. In order to achieve school quality, influencing factors such as the managerial ability of the principal and teacher performance have a significant influence. In connection with this statement, the results of research (Idris, 2017) show that simultaneously the principal leadership orientation and teacher performance have a significant effect on the quality of education. The contribution of the influence of principal leadership orientation and teacher performance on 
school quality is $47.0 \%$, while $53.0 \%$ school quality is influenced by variables other than leadership of principal orientation and teacher performance at state elementary school 2 Tanjung.

Based on the opinions and results of the research above, that there is an influence of principal managerial ability and teacher performance on school quality with proves the theory which states a positive increase that occurs in the managerial ability of principals and teacher performance will improve the quality of schools.

\section{Conclusion}

Based on the results of hypothesis testing and data analysis regarding the influence of principal managerial ability and teacher performance on school quality, the following conclusions are obtained: The results of hypothesis testing indicate that the managerial ability of the principal affects the quality of the school by $63.7 \%$. This can be interpreted that the variation that occurs in the variable of the managerial ability of the principal is predicted to improve the quality of the school. Furthermore, the results of hypothesis testing indicate that teacher performance has a relationship with school quality and has an effect of 58.6\%. This can be interpreted that teacher performance as an independent variable has a positive and significant effect on school quality as the dependent variable and this means that the second research hypothesis can be accepted. Finally, there is the effect of principal managerial ability and teacher performance on school quality by $68.2 \%$, meaning that principal managerial ability and teacher performance as independent variables have a positive and significant effect on school quality as the dependent variable, meaning that the three research hypotheses can be accepted.

To improve the quality of high schools in Way Kanan district, it is necessary to check the procurement of facilities and infrastructure that support the learning process from the education office. In addition, school principals are required to improve their competence through training and by attending further education. The professional competence of teachers can be improved by participating in various training activities and taking an active role in them

\section{Acknowledgements}

The author would like to thank the respondents of high school teachers throughout Way Kanan district who have taken the time and fully supported this research.

\section{Funding}

This research received no specific grant from any funding agency in the public, commercial, or not-forprofit sectors.

\section{References}

Arcaro, J. S. (2005). Quality Based Education, Principles and Procedures for Implementation. Yogyakarta: Pustaka Pelajar.

Arcaro, J. S., Asep, H., \& Hermawan. (2018). Curriculum Development and Learning. Jakarta: Universitas Terbuka.

Aspin, N. D., Chapman, D. J., \& Wilkinson, H. V. (1994). Quality schooling: A pragmatic approach tackles the current problems, topics and issues. Lodon: Cassell.

Azhari, U. L., \& Kurniadi, D. A. (2016). Education Financing Management, Learning Facilities, and School Quality. Journal of Educational Administration, 13(2), 21.

Barkah, J. (2017). Improving Teacher Performance Through Principal Managerial Ability and Organizational Climate in Madrasah. Sosio E-Kons, 6(1), 6.

Damayanti, D. (2017). Principal Managerial Ability, School Climate and Elementary School Quality. Journal of Educational Administration, 24(1), 154-162.

Engkoswara, \& Komariah, A. (2010). Education Administration. Bandung: Alfabeta.

Ghazzawi, K., Shoughari, R., \& Osta, B. E. (2017). Situational Leadership and Its Effectiveness in Rising Employee Productivity A Study on North Lebanon Organization. Human Resource Management Research, 7(3), 102-110.

Haningsih, S. (2014). Implementation of the Education Quality Program in Improving Academic Culture at Madrasah Aliyah Sunan Funding (Maspa) Sardoharjo Ngaglik Sleman DIY. El-Tarbawi, 7(1).

Hersey, P. B. (2012). Organizational Behavior Management, Translation: Agus Dharma. Erlangga.

Idris, A. (2017). The Influence of Principal Leadership Orientation and Teacher Performance on Education Quality at State Elementary School 2 Tanjung. Management Partner Journal, 1(2).

Junianto, D., \& Wagiran, W. (2013). The Effect of Teacher Teaching Performance, Parental Involvement, Self Actualization and Achievement Motivation on Achievement. Journal of Vocational Education, 3(3), 307-319. https://doi.org/10.21831/jpv.v3i3.1845

Kosim, N. (2007). The Relationship between Emotional Intelligence and Teacher Performance at Elementary School IT Nur Fatahillah Pondok Benda Buaran Serpong. Jakarta: Syarif Hidayatullah State Islamic University Jakarta.

Kuswana, H. (2019). The Effect of Managerial Capabilities of Principal Toward School Quality in Vocational High School. Journal of Educational Leadership, 2(1). https://doi.org/10.22236/jkpuhamka.v2i1.3805

Laksmi, N. L. P. S., Agung, A. A. G., \& Sudirman. (2019). The Relationship of Servant Leadership, Principal Managerial Competence, Organizational Culture, and Work Motivation with Teacher Performance in the Tunjung PAUD Cluster, North Denpasar District. Journal of Education Administration Indonesian, 10(2), 148-156. https://doi.org/10.23887/japi.v10i2.2802

Law No 20 of 2003 Concerning The National Education System. (n.d.).

Lunenburg, \& Irby. (2006). The Principalship, Vision to Action. Cengange Learning.

Mudiyantun, Y. (2019). The Investigation of Situational Leadership, and Work Motivation on Kindergarden Teacher Performance. Journal of Educational Leadership, 2(1). https://doi.org/10.22236/jkpuhamka.v2i1.3814

Mulyani, A. (2012). The Effect of Principa Performance and Teacher Performance on Learning Quality at Purwakarta District Vocational High School. Journal of Educational Administration, 14(1). 
Mustikeni. (2019). Teacher Performance Improvement Through Collaborative Educational Supervision at Elementary School 2 Setanggor. Journal of Education and Science, 1(2). https://ejournal.stitpn.ac.id/index.php/edisi/article/view/414

Nasution, M. N. (2001). Integrated Quality Management (Total Quality Management. Ghalia Indonesia.

National Education, M. (2002). Summary of Teaching and Learning Activities. Ministry of National Education.

Putrayana, G. K., Agung, A., \& Sunu, I. (2018). Analysis of Determination of Principal Leadership Style, Quality Management, Work Environment and Work Commitment to Job Satisfaction of Teachers at State Senior Hugh School 1 Mengwi. Journal of Indonesian Education Administration, 9(1), 77-87.

Salim, N. A. (2017). Increasing the Effectiveness of School Management through Strengthening the Managerial Capability of Principals. Journal of Educational Management and Supervision, 2(1), 8-16.

Sallis, E. (2002). Total Quality Management in Education(3 ed.) (Education(). London: Kogan Page, Ltd.

Sedarmayanti. (2010). Human Resources and Work Productivity. Bandung: CV Mandar Maju.

Siswanto, H. (2011). Introduction to Management. Jakarta: Bumi Aksara.

Soedijarto. (2011). Learning Motivation. Jakarta: Rineka Cipta.

Sugihartini, N. M., Agung, A. A. G., \& Dantes, K. R. (2018). The Contribution of the Implementation of School Management Based on Tri Hita Karana's Local Wisdom Values, Principal Servant Leadership and Job Satisfaction on Teacher Organizational Commitment at State Junior High School Singaraja Buleleng. Journal of Indonesian Education Administration, 9(2), 111-120. https://doi.org/10.23887/japi.v9i2.2776

Sugiyono. (2017). Metode Penelitian Kuantitatif, Kualitatif, dan R\&D. Bandung : CV. Alfabeta.

Suharsaputra, U. (2010). Education administration. Bandung: Refika Aditama.

Sulaefi. (2017). The Effect of Training and Development on Work Discipline and Employee Performance. Journal of Entrepreneurial Management, 5(1). http://jurnal.unmer.ac.id/index.php/jmdk/article/view/1212.

Suyatno, T. (2010). Determinants of The Quality of Public High School Education in Jakarta. Journal of Educational Administration.

Teacher and Lecturer Law No. 14 of 2005 Article 8 and Permendiknas No. 13 of 2007 Concerning School Principal Performance Standards. (n.d.).

Terry, G. R. (1972). Priciples of Management(6 ed). Richard D. Irwin Homewood.

Timur, H., Saud, S. U., \& Suhardan, D. (2009). School Quality: Between Principal Leadership and Teacher Performance. Journal of Educational Administration, 15(1), 11.

Wahyudi. (2009). Principal Leadership; in a learning organization. Bandung: Alfabeta.

Wibowo. (2007). Performance management. Jakarta: PT Rajagrafindo Persada.

Yayuk, S., \& Sugiyono, S. (2019). The Influence of Principals Leadership and Education Costs on The Quality of The Teacing and Learning Process and their Impact on The Competence of Vocational High School graduates in Gunungkidul district. Journal of Educational Management Accountability, 7(1), 84-96. https://doi.org/10.21831/amp.v7il.23758

Zeithaml, V. A., \& Bitner, M. J. (2002). Service marketing: Integrating customer focus accross the. In The Mc. Graw-Hill Companies (firm(3, pp. 12-14). 